Secondly, and presumably because of the dogma that "animals have no souls", he never touches on the large and exciting field of comparative psychology, or on the evolution of the behaviour-patterns and instinctive responses which mankind has so obviously inherited and to which all post-Freudian analysis has directed attention. The idea that each and every "intellectual soul" of man is a special divine creation if tenable must surely be adjusted now so as to allow room for an age-old substratum of animalisms conditioning our mind and morals as they do our bodies.

Thirdly, he writes always within the strait-jacket of Papal orthodoxy, much of it formulated in preCopernican and all of it except one encyclical in pre-Darwinian days. Though much of this may be held to deal with matters outside the range of presentday science, it has, even so, corollaries of dogmatic status, for example, the historicity of Adam and Eve, which bear directly on his theme. Moreover, does he really think that in matters demanding not only religious but also scientific, historical and ethical experience, the Vatican is the proper and infallible authority to which every other expert must yield unquestioning obedience? CharLes E. Raven

\section{CLIMATES OF THE PAST}

\section{Descriptive Palaeoclimatology}

Edited by A. E. M. Nairn. Pp. $x i+380$. (New York: Interscience Publishers, Inc.; London: Interscience Publishers, Ltd., 1961.) 11 dollars; $80 s$.

GEOLOGISTS who have struggled to interpret I past climates will welcome this book for its wealth of factual information and for the critical way in which most of the authors have approached their special interests.

The first chapter, apart from a brief introduction by the editor, is a summary by Lamb of the nature and causes of the world's climate to-day. It is not easy to read, but it is extremely informative. Then follows a series of chapters each written by a specialist and dealing with the separate criteria which can be used as a means of assessing at least some facet of climate. These may be pure physical measurements (palæomagnetism, the ratio of oxygen-16 to oxygen-18), geological observations (the dips of æolian sandstones, the evidence of the presence and extent of ice), physical chemistry (evaporites and red beds) or biological deductions (from vertebrate, invertebrate or plant fossils). Finally, there are four chapters in which are traced the climatic changes over a large part of geological time in Europe and North America, the Far East and Gondwanaland.

Flint, dea!ing with glaciation, perhaps stands on the firmest ground, for the conversion of water to ice has a well-known climatic relationship and the presence of glaciers or permanently frozen ground in many cases gives rise to conclusions about climate which are without ambiguity. Much more difficult to interpret are evaporites and red beds, and the authors of these sections are understandably cautious in their conclusions. This welcome attitude is indeed apparent throughout. In dealing with the oxygen isotopes, for example, Thorley does a great service in pointing out the assumptions which have to be made before this method can be used for temperature determinations-assumptions which can too easily be ignored by stratigraphers eager to use a physicist's measurements to support a theory.
Perhaps the biologists are the most cautious of the authors, for all stress the difficulty of using the present as a key to the past when ancient floras and faunas are specifically and generically so different from those of to-day. On the whole, the greatest reliance is placed on anatomy, for it seems that certain modifications of structure, similar in widely diverse creatures, are adaptations to certain extremes of climate.

Throughout the book, emphasis is placed on polar wandering and continental drift. The palæomagnetists accept it without question, for their results would be largely meaningless without it, but they still have a long way to go before they present a conclusive and agreed story. Thus Nairn's equator-positions for the Trias of Europe (Chapter 7, Fig. 9), Africa and North America (Fig. 7) seem to provide an insoluble problem of drift if his three lines are to join into a continuous girdle at one moment of time. The palæontologists are more non-committal about polar shift, while conceding the necessity for great climatic change in the present polar regions. Van Houten's examination of the significance of red beds tends to support wandering rather than static poles, but, on the other hand, Green feels able to explain the distribution of evaporites without recourse to drift or polar change.

As a whole, the book is a mine of information and both a stimulus to enthusiasm and a corrective to over-enthusiasm in approaching a difficult problem. Its copious references are international in character though scanty from beyond the Iron Curtain. It would be churlish to point out a few misprints and errors of translation and more to the point to congratulate the editor on welding together the contributions of fifteen authors from seven countries.

F. W. SноттоN

\section{BIRDS OF TROPICAL PARADISE}

\section{Birds of Trinidad and Tobago}

By Dr. G. A. C. Herklots. Pp. $287+20$ plates. (London: William Collins, Sons and Co., Ltd., 1961.) 42s. net.

THE islands of Trinidad and Tobago, the southern. most of the West Indian chain, have a combined land area of about 2,000 square miles, Tobago being very much the smaller, and at $10^{\circ} \mathrm{N}$. and about 10 miles from Venezuela on the South American mainland, they are truly tropical. Being small islands they possess a high proportion of coastal land; in Trinidad there is a range of mountains (in the north) topping $3,000 \mathrm{ft}$. in two places, abundant deep forests, lowland plains, savannahs and extensive swamps; a wide range of habitats that encourage a wide variety of bird species both exotic and interesting.

Without undertaking an expensive safari (of the type so popular with programmers of television) one may seek out and enjoy the sight of a flock of flamingoes (Eudocimus ruber) either feeding in swampy land or, at sunset, a blaze of scarlet glory winging its way to roost - a sight not easily forgotten. I have, indeed, photographed a group of these birds feeding quietly on a plot of low-lying coastal land not two miles from the capital city, Port of Spain.

From the islands off the north-west peninsula one may film with ease the superb aerobatic displays of flocks of frigate-birds (Fregata magnificens--wingspan up to $7 \mathrm{ft}$.) as they swoop gracefully to snatch small fish from the surface of the sea with a downward flick 